\title{
Sand Size Affects Topdressing Removed by Mowing and Anthracnose on Annual Bluegrass Putting Green Turf
}

\author{
Ruying Wang, James W. Hempfling, Bruce B. Clarke, \\ and James A. Murphy \\ Department of Plant Biology, Rutgers, the State University of New Jersey, 59 \\ Dudley Road, New Brunswick, NJ 08901
}

Additional index words. Colletotrichum cereale, particle size distribution, Poa annua, volumetric water content

\begin{abstract}
Sand size can affect the ability to incorporate topdressing into the turf canopy and thatch on golf course putting greens; unincorporated sand interferes with mowing and play. This 3-year field trial was initiated to determine the effects of sand size on sand incorporation, surface wetness, and anthracnose (caused by Colletotrichum cereale Manns sensu lato Crouch, Clarke, and Hillman) of annual bluegrass [Poa annua $\mathrm{L}$. $\mathrm{f}$. reptans (Hausskn) T. Koyama] maintained as a putting green. The experimental design was a randomized complete block with four replications; treatments included a non-topdressed control and three topdressing sands (medium-coarse, medium, or medium-fine) applied every 2 weeks at $0.15 \mathrm{~L} \cdot \mathrm{m}^{-2}$ during the summer. Topdressing with medium-coarse sand was more difficult to incorporate than the medium and medium-fine sands, resulting in a greater quantity of sand collected with mower clippings. Analyzing the particle distribution of sand removed by mowing confirmed that coarser sand particles were more likely to be removed in mower clippings. Surface wetness measured as volumetric water content (VWC) at the 0 - to 38-mm depth zone was greater in non-topdressed plots than topdressed plots on $35 \%$ of observations. Few differences in VWC were found among sand size treatments. Turf responses to topdressing were not immediate; however, as sand accumulated in the turf canopy, topdressed plots typically had lower anthracnose severity than non-topdressed turf after the first year. Additionally, topdressing with medium and medium-fine sands produced similar or occasionally lower disease severity than topdressing with medium-coarse sand. The lack of negative effects of medium and medium-fine sands combined with better incorporation after topdressing and less disruption to the putting surface should allow golf course superintendents to apply topdressing at frequencies and/or quantities needed during the summer to maintain high-quality turf and playing conditions.
\end{abstract}

Frequent, light sand topdressing is commonly practiced on golf course putting greens during the playing season to maintain firm, smooth surfaces and modify accumu-

\footnotetext{
Received for publication 6 Aug. 2019. Accepted for publication 16 Oct. 2019.

Published online 21 January 2020.

We thank T.J. Lawson for assistance in maintaining the study area. This work was supported by the U.S. Department of Agriculture National Institute of Food and Agriculture Hatch Multistate Project 0206183 through the New Jersey Agricultural Experiment Station, Hatch Multistate Project NJ12294. Additional support was provided by the Rutgers Center for Turfgrass Science, United States Golf Association, Golf Course Superintendents Association of America, Golf Course Superintendents Association of New Jersey, Tri-State Turf Research Foundation, and New Jersey Turfgrass Foundation.

J.A.M. is the corresponding author. E-mail: jamurphy@ njaes.rutgers.edu.

This is an open access article distributed under the CC BY-NC-ND license (https://creativecommons. org/licenses/by-nc-nd/4.0/).
}

lating thatch (Vavrek, 1995). Heavy topdressing rates increase wear on mower reels and bedknives when topdressing is not fully incorporated into the turf canopy and thatch (Foy, 1999; Murphy, 2012; Vavrek, 1995). Damage to mowers as well as interference to play due to unincorporated sand particles discourages golf course superintendents from routinely implementing topdressing during the growing season.

Sand size distributions specified for putting green construction are often used as guidelines to select topdressing sand, which typically recommend sand containing less than $20 \%$ fine $(0.15-0.25 \mathrm{~mm})$ particles [United States Golf Association (USGA) Green Section Staff, 2004; Table 1]. Recently, some managers have adopted the use of medium-fine sand that lacks very coarse (1-2 mm) and coarse $(0.5-1 \mathrm{~mm})$ particles to improve the incorporation of topdressing sand (Murphy, 2012; Pippin, 2010; Stahl, 2013). Very coarse and coarse particles are more likely to remain on turf surface, whereas finer sized sand particles more easily filter into the turf canopy (Stier and Hollman, 2003; Taylor, 1986). Additionally, finer sands may also be less expensive to purchase than sands conforming to USGA specifications (Henderson et al., 2010). However, an excess quantity of fine sand in the root zone of a putting green can potentially reduce air-filled porosity and saturated hydraulic conductivity compared with coarse or coarse-medium sand (Murphy et al., 2001).

Fine sand tended to retain more water in the top $5 \mathrm{~cm}$ of the root zone than USGA specified sand and coarse sand (Henderson et al., 2010). Moeller (2008) reported that core aeration twice a year and topdressing with a sand finer than the underlying root zone increased fine sand content at the 0 - to $5.7-\mathrm{cm}$ root zone depth in the third year. However, that use of the finer sand did not impede turfgrass performance, and in fact, turf color was sometimes improved, likely due to greater water retention (Moeller, 2008).

Anthracnose, caused by the fungus Colletotrichum cereale Manns sensu lato Crouch, Clarke, and Hillman, is a major disease of cool-season turfgrasses throughout the world (Landschoot and Hoyland, 1995; Mann and Newell, 2005; Smiley et al., 2005). Anthracnose is particularly severe on annual bluegrass [Poa annua L. f. reptans (Hausskn) T. Koyama] putting greens (Smiley et al., 2005). Sand topdressing programs can improve turf quality and suppress the severity of anthracnose on annual bluegrass putting green turf (Hempfling et al., 2015, 2017; Inguagiato et al., 2012, 2013; Roberts and Murphy, 2014; Wang et al., 2018). Inguagiato et al. (2013) found that particle shape of topdressing sand had no effect on anthracnose. However, it is not known whether the size of topdressing sand affects anthracnose severity.

Because of the potential for detrimental effects, research is needed to investigate the effects of topdressing with finer-textured sand on the performance characteristics of turf before it can be recommended for use on golf courses. The objectives of this research were to determine the effects of sand size on efficiency of incorporation, surface water retention, and anthracnose severity of annual bluegrass turf managed as a putting green.

\section{Materials and Methods}

Research methodology. A 3-year field study was initiated in mid-June 2011 on annual bluegrass turf grown on a Nixon sandy loam (fine-loamy, mixed, mesic Typic Hapludaults) and maintained as a putting green at the Rutgers Horticulture Farm No. 2 in North Brunswick, NJ. This monostand of annual bluegrass was established in Sept. 2002 as described by Inguagiato et al. (2009). The annual bluegrass turf was originated from the soil seed bank as well as the soil cores collected from Plainfield Country Club, Plainfield, NJ, in 1998 (Samaranayake et al., 2008). The field was renovated in 2008 with heavy topdressing and core aeration and routinely topdressed afterward with mediumcoarse sand conforming to USGA guidelines 


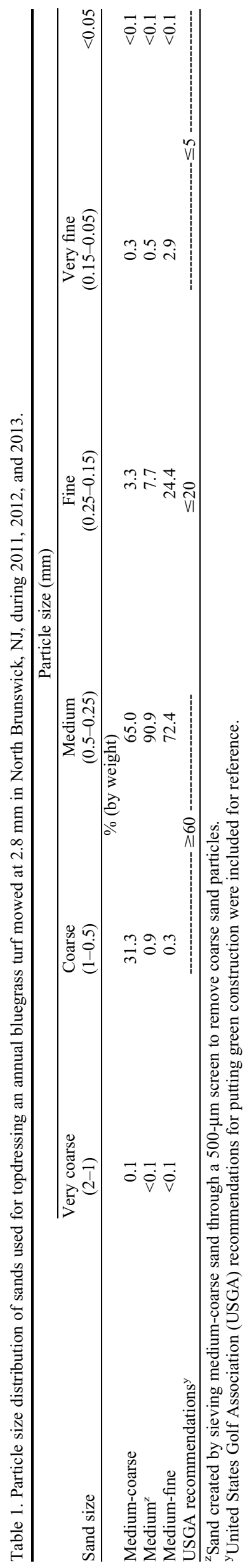

(USGA Green Section Staff, 2004) consistently across the entire field, resulting in an $\approx 60$-mm-deep topdressed mat layer above the sandy loam. The topdressing treatments in this trial were a non-topdressed control and three sand sizes (Table 1) arranged in a randomized complete block design, replicated four times, and applied to the same plots location over three growing seasons. Medium-coarse sand (310; U.S. Silica, Co., Mauricetown, NJ), medium sand (coarse particles removed from medium-coarse sand with a $500-\mu \mathrm{m}$ sieve), and medium-fine sand (Drier 50; U.S. Silica, Co.) were applied at $0.15 \mathrm{~L} \cdot \mathrm{m}^{-2}$ every 2 weeks from 26 July to 29 Aug. 2011, 19 June to 11 Oct. 2012 and 18 June to 3 Oct. 2013. Additional applications were made at 0.3 $\mathrm{L} \cdot \mathrm{m}^{-2}$ on 11 July 2011, 23 May 2012, 5 June 2012, 16 Nov. 2012, 20 May 2013, 4 June 2013, and 14 Nov. 2013 and at $0.6 \mathrm{~L} \cdot \mathrm{m}^{-2}$ on 13 June 2011, 27 June 2011, 21 Oct. 2011, 4 Nov. 2011, 10 Apr. 2012, 24 Apr. 2012, 17 Oct. 2012, 10 Apr. 2013, 24 Apr. 2013, and 29 Oct. 2013. The annual total quantity of sand applied was $3.45 \mathrm{~L} \cdot \mathrm{m}^{-2}(\approx 3.5 \mathrm{~mm})$ in 2011 and 3.90 $\mathrm{L} \cdot \mathrm{m}^{-2}(\approx 3.9 \mathrm{~mm})$ in 2012 and 2013. Sand was measured for each treatment, applied with a drop spreader (model SS-2; The Scotts Company, Marysville, $\mathrm{OH}$ ), and incorporated immediately after topdressing with a stiff-bristled brush (Harper Brush Works, Inc., Fairfield, IA). Individual plots were brushed uniformly by manually pulling the brush across each half of the plot four times in two directions. Sand topdressing was never applied as a broadcast application during the study.

Data collection. The completeness of sand incorporation after topdressing was assessed visually on a 1 to 9 scale, where 9 represented complete incorporation of sand into the turf canopy and 5 represented a visible but acceptable quantity of sand remaining (unincorporated) on the surface of turf canopy. To quantify unincorporated sand, clippings were occasionally collected the day after topdressing with a walk-behind mower (Toro Greensmaster 1000; Bloomington, $\mathrm{MN}$ ) at bench-setting of $3.4 \mathrm{~mm}$ equivalent to daily mowing with a triplex greens mower (model 3150; Toro Co., Bloomington, $\mathrm{MN}$ ) at bench-setting of $2.8 \mathrm{~mm}$. No irrigation or rain occurred between application of topdressing treatments and the collection of clippings. Clippings were collected five times from 14 June to 23 Aug. 2011, twice on 11 April and 1 Aug. 2012, and three times from 25 April to 19 June 2013. Clipping samples were dried at $55^{\circ} \mathrm{C}$ for $72 \mathrm{~h}$ and combusted in a muffle furnace at $600{ }^{\circ} \mathrm{C}$ for $4 \mathrm{~h}$. Sand was separated from ash using a $106-\mu \mathrm{m}$ sieve and weighed as described by Johnston et al. (2005). Particle size distribution was then determined by sieving each sample for $5 \mathrm{~min}$ with a Ro-Tap sieve shaker (RX-29; W.S. Tyler, Mentor, $\mathrm{OH}$ ). Sand weights were converted to $\mathrm{g} \cdot \mathrm{m}^{-2}$. VWC was measured with time domain reflectometry (Field Scout TDR 300 model; Spectrum Technologies, Inc., Plainfield, IL) equipped with $38-\mathrm{mm}$ probes, and probes were inserted vertically into the turf plots. The average of four VWC mea- surements taken per plot was used for statistical analysis. Anthracnose severity was visually assessed five times from 24 June to 16 Aug. 2011, four times from 27 June to 6 Aug. 2012, and five times from 14 June to 7 Aug. 2013 using a line intercept-grid count method described by Inguagiato et al. (2008).

General field maintenance. Turf was mowed $6 \mathrm{~d}$ per week with clippings collected during the growing season with a triplex greens mower (model 3150; Toro Co., Bloomington, MN) at a bench-setting of $2.8 \mathrm{~mm}$. Plots were rolled three to five times a week with a smooth pavement roller $(1.7 \mathrm{t}$ tandem vibratory roller, Model RD11A; Wacker Neuson, Munich, Germany) to smooth the surface and simulate traffic. Overhead irrigation and hand watering were applied to obtain moderately dry and uniform soil water content similar to a golf course setting. Fertilizers and plant growth regulators were applied as reported by Wang et al. (2018). The mat layer $\mathrm{pH}$ was 5.4, 6.2, and 6.4, and the underlying soil $\mathrm{pH}$ was $6.1,5.9$, and 6.0 in 2011, 2012, and 2013, respectively. Dolomitic limestone was applied at $61 \mathrm{~kg} \cdot \mathrm{ha}^{-1}$ on 24 Sept. 2011. Gypsum $\left(\mathrm{CaSO}_{4} \cdot 2 \mathrm{H}_{2} \mathrm{O}\right)$ was applied at $634 \mathrm{~kg} \cdot \mathrm{ha}^{-1}$ on 29 June 2012 . Sand incorporation data were not taken when particles of dolomitic limestone and gypsum were present on the turf surface. Other fungal diseases, annual bluegrass weevils, and algae (cyanobacteria) were controlled by chemicals with limited effects on anthracnose with the same applications reported by Wang et al. (2018).

Chlorothalonil (tetrachloroisophthalonitrile) at $12.6 \mathrm{~kg}$ a.i./ha, fosetyl-Al (O-ethyl phosphonate) at $9.8 \mathrm{~kg}$ a.i./ha, tebuconazole $(\alpha-[2-(4-$ chlorophenyl)ethyl]$\alpha$-(1,1-dimethylethyl)-1H-1,2,4-triazole1-ethanol) at $0.7 \mathrm{~kg}$ a.i./ha, or polyoxin D zinc salt $(1: 1)$ \{Zinc 5-[[2-amino-5-O(aminocarbonyl)-2-deoxy-L-xylonoyl] amino]-1-(5-carboxy-3,4-dihydro-2,4-dioxo$1(2 \mathrm{H})$-pyrimidinyl)-1,5-dideoxy- $\beta$-D-allofuranuronate $\}$ at $0.3 \mathrm{~kg}$ a.i./ha was applied to the entire trial every $14 \mathrm{~d}$ from $13 \mathrm{Aug}$. to 26 Oct. 2011 to arrest the anthracnose epiphytotic and promote turf recovery. In 2012, anthracnose was suppressed with chlorothalonil at $16.1 \mathrm{~kg}$ a.i./ha on $17 \mathrm{Aug}$. and then every 8 to $12 \mathrm{~d}$ from 24 Aug. to 5 Oct. at 12.6 $\mathrm{kg}$ a.i./ha and $10.1 \mathrm{~kg}$ a.i./ha on 5 November. In 2013, chlorothalonil was applied alone at $12.6 \mathrm{~kg}$ a.i./ha on 9 Aug., 16 Aug., 3 Sept., and $21 \mathrm{Sept}$. and at $8.1 \mathrm{~kg}$ a.i./ha on 18 Oct., and in a tank mixture with tebuconazole at 8.1 $\mathrm{kg}$ a.i./ha and $0.7 \mathrm{~kg}$ a.i./ha, respectively, on 2 October. Additionally, metconazole (5-[(4chlorophenyl)methyl]-2,2-dimethyl-1-(1H-1,2,4triazole-1-ylmethyl)cyclopentanol) was applied at $0.6 \mathrm{~kg}$ a.i./ha on $30 \mathrm{Aug} .2013$.

Data analysis. Data were subjected to analysis of variance using the general linear model procedure in the Statistical Analysis System software v. 9.3 (SAS Institute Inc., Cary, NC), and orthogonal contrasts were performed to compare treatments at the $0.05 P$ level. Repeatedmeasures analysis indicated significant 
time-by-treatment interactions, and therefore, data were analyzed separately on each observation date.

\section{Results}

Sand incorporation. Less sand was observed on the turf canopy after topdressing with finer sands than the medium-coarse sand on 10 of 13 visual rating dates during 2011, 2012, and 2013 (Table 2). Moreover, medium-fine sand incorporated into the turf better than medium sand on five of 13 rating dates during 2011, 2012, and 2013 (Table 2). The level of medium-fine sand incorporation within the day of or $1 \mathrm{~d}$ after topdressing was acceptable $(\geq 5)$ on 11 of 13 dates during the study compared with 10 dates for medium sand and eight dates for medium-coarse sand.

The quantities of topdressing removed by mowing varied in different seasons. Less than $1.2 \%$ of the topdressing applied was removed by mowing in April of 2012 and 2013 (Table 3). The first mowing generally picked up $1.4 \%$ to $5.5 \%$ of the topdressing applied (Table 3). However, a substantial amount of the applied medium-coarse sand topdressing (>10\%) was removed on 1 Aug. 2012 and 5 June 2013 (Table 3). Consistent with visual observations, significantly less sand was removed with mower clippings from plots topdressed with finer sands compared with plots treated with medium-coarse sand on six of 10 dates during 2011, 2012, and 2013 (Table 3).
The quantity of sand collected in the clippings from plots topdressed with medium-fine sand was lower than plots topdressed with medium sand on two of 10 dates.

Consistently greater quantities of coarsesized particles were removed by mowing on plots topdressed with medium-coarse sand compared with finer sands (Fig. 1), which was consistent with the medium and medium-fine sands used for topdressing that had no more than $1 \%$ coarse-sized particles by weight (Table 1). The quantity of medium-sized particles removed from plots topdressed with medium-coarse sand was similar or less (on 11 Apr. 2012) than plots topdressed with finer sands (Fig. 1). More medium-sized particles were removed from plots topdressed with medium sand than plots topdressed with medium-fine sand on four of 10 samplings across 3 years (Fig. 1). Similar or significantly less (five of 10 dates) fine-sized sand particles were removed from plots topdressed with medium-coarse sand compared with plots with the finer sands, whereas more fine-sized sand particles were collected in grass clippings from plots topdressed with medium-fine sand than medium sand on two dates (Fig. 1). A limited quantity $\left(<0.3 \mathrm{~g} \cdot \mathrm{m}^{-2}\right)$ of sand particles coarser than $1 \mathrm{~mm}$ or finer than $0.15 \mathrm{~mm}$ was found in each sample and therefore will not be discussed further.

Volumetric water content. In the first year, the VWC of non-topdressed plots were similar to that of the topdressing treatments (Fig. 2). As sand treatment accumulated, all topdressed plots had significantly lower VWC than nontopdressed plots on 13 of 23 dates during 2012 and 2013 (Figs. 3 and 4). Few differences in VWC were observed among the three topdressing sand sizes in this trial. Plots topdressed with medium-coarse sand had lower VWC than plots topdressed with finer sands on two dates in 2011 (20 June and 22 Aug.; Fig. 2). Mediumfine sand treatment had greater VWC than medium sand plots on two dates in 2012 (16 May and 30 July; Fig. 3).

Disease severity. Anthracnose was first observed in late June 2011 as a natural infection, developed slowly before dramatically increasing to peak disease severity (55\% to $74 \%$ ) on 5 Aug., then decreased slightly to $55 \%$ to $67 \%$ turf area infected on 16 Aug. (Table 4). Disease occurred again in mid- to late-June and gradually increased to a maximum of $27 \%$ to $44 \%$ and $54 \%$ to $71 \%$ in early August in 2012 and 2013, respectively (Table 4).

In the initial year, topdressing treatments did not affect anthracnose severity compared with non-topdressed; however, plots topdressed with medium-fine sand had $12 \%$ less area infected than plots topdressed with medium sand on the last observation date in 2011 (Table 4). All sand treatments suppressed disease compared with the nontopdressed plots throughout 2012 (Table 4). Similarly, topdressing treatments suppressed disease on four of five rating dates in 2013 (Table 4). Finer sands produced equivalent or

Table 2. Sand incorporation response on an annual bluegrass turf mowed at $2.8 \mathrm{~mm}$ and topdressed with three sand sizes in North Brunswick, NJ, during 2011, 2012 , and 2013.

\begin{tabular}{|c|c|c|c|c|c|c|c|c|c|c|c|c|c|}
\hline \multirow[b]{2}{*}{ Sand size } & \multirow{2}{*}{$\begin{array}{l}\frac{2011}{4 \text { Nov. }} \\
\left(0 \text { DAT }^{z}\right)\end{array}$} & \multicolumn{4}{|c|}{2012} & \multicolumn{8}{|c|}{2013} \\
\hline & & $\begin{array}{l}11 \text { Apr. } \\
\text { (1 DAT) }\end{array}$ & $\begin{array}{l}25 \text { Apr. } \\
\text { (1 DAT) }\end{array}$ & $\begin{array}{l}\text { 20 June } \\
\text { (1 DAT) }\end{array}$ & $\begin{array}{l}26 \text { Sept. } \\
\text { (0 DAT) }\end{array}$ & $\begin{array}{l}10 \text { Apr. } \\
(0 \text { DAT })\end{array}$ & $\begin{array}{l}24 \text { Apr. } \\
\text { (0 DAT) }\end{array}$ & $\begin{array}{l}4 \text { June } \\
\text { (0 DAT) }\end{array}$ & $\begin{array}{c}5 \text { June } \\
(0 \mathrm{DAT})\end{array}$ & $\begin{array}{c}5 \text { July } \\
(0 \text { DAT })\end{array}$ & $\begin{array}{c}7 \text { July } \\
\text { (0 DAT) }\end{array}$ & $\begin{array}{l}15 \text { July } \\
\text { (0 DAT) }\end{array}$ & $\begin{array}{l}3 \text { Oct. } \\
\text { (0 DAT) }\end{array}$ \\
\hline & & & & & & & $1-9$ scale $^{y}$ & & & & & & \\
\hline Medium-coarse (MC) & 7.3 & 6.3 & 6.6 & 7.9 & 2.0 & 3.0 & 4.0 & 4.9 & 5.4 & 6.0 & 7.8 & 5.3 & 4.8 \\
\hline Medium (M) & 7.8 & 7.3 & 6.6 & 8.0 & 3.3 & 4.3 & 4.6 & 5.3 & 5.9 & 7.0 & 9.0 & 6.3 & 5.5 \\
\hline Medium-fine (MF) & 7.3 & 7.6 & 7.9 & 8.3 & 4.8 & 4.5 & 5.3 & 6.0 & 7.0 & 7.5 & 9.0 & 6.8 & 6.3 \\
\hline Orthogonal contrasts & & & & & & & $P>F$ & & & & & & \\
\hline $\mathrm{CV}(\%)$ & 6.1 & 6.7 & 6.8 & 4.3 & 9.9 & 8.0 & 5.5 & 5.3 & 7.0 & 8.8 & 2.9 & 5.0 & 7.8 \\
\hline
\end{tabular}

${ }^{\mathrm{z}}$ Number of days after topdressing (DAT); 0 DAT $=$ ratings were taken on the same day after topdressing.

${ }^{\mathrm{y}}$ Completeness of sand incorporation, where 9 represents no sand visible at turf surface, and 5 represents the minimally acceptable rating.

Ns, ${ }^{*}, * *, * * *$ Nonsignificant or significant at $P \leq 0.05,0.01$, or 0.001 , respectively.

Table 3. Sand quantities in mower clippings collected the next day after topdressing from an annual bluegrass turf mowed at $2.8 \mathrm{~mm}$ as affected by three sand sizes in North Brunswick, NJ during 2011, 2012, and 2013.

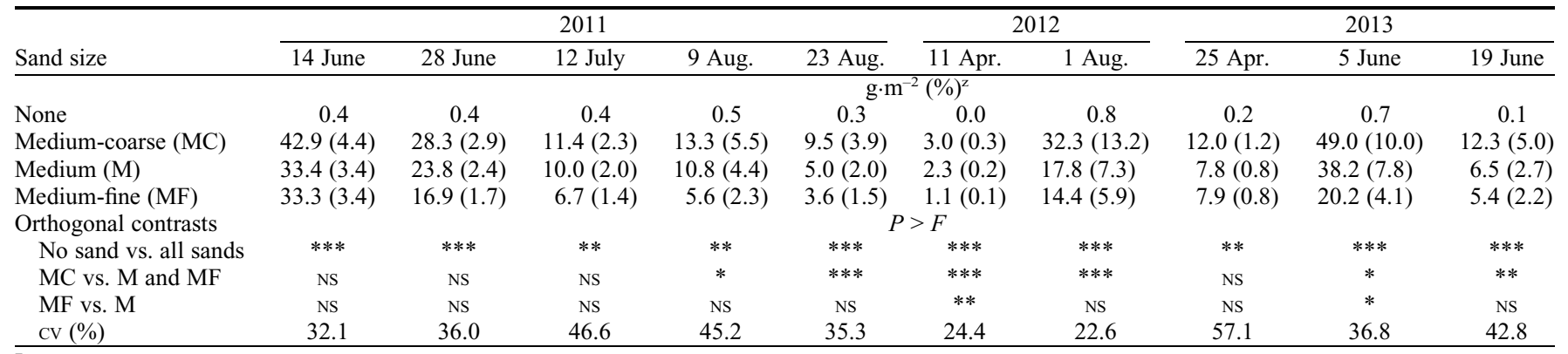

${ }^{\mathrm{z}}$ Numbers in parentheses indicate the percentage of the total sand applied that was collected in the mower clippings.

Ns, ${ }^{*, * *}, * * *$ Nonsignificant or significant at $P \leq 0.05,0.01$, or 0.001 , respectively. 


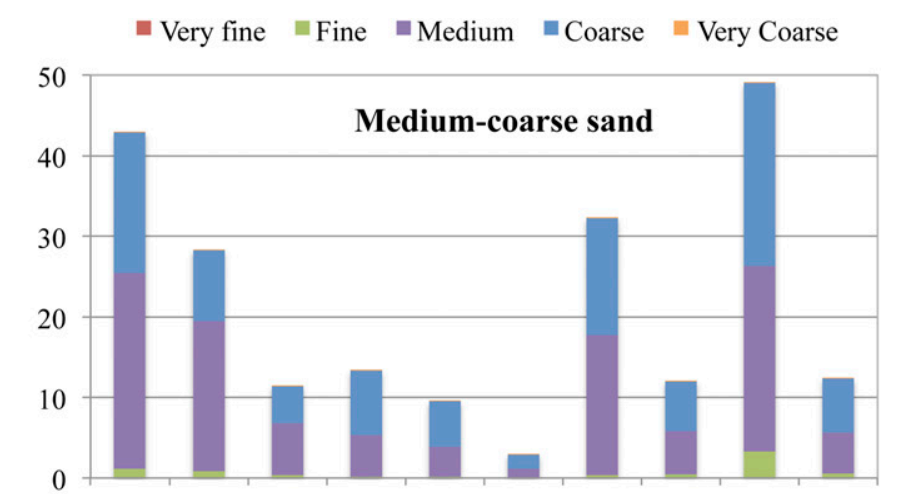

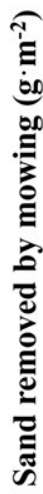
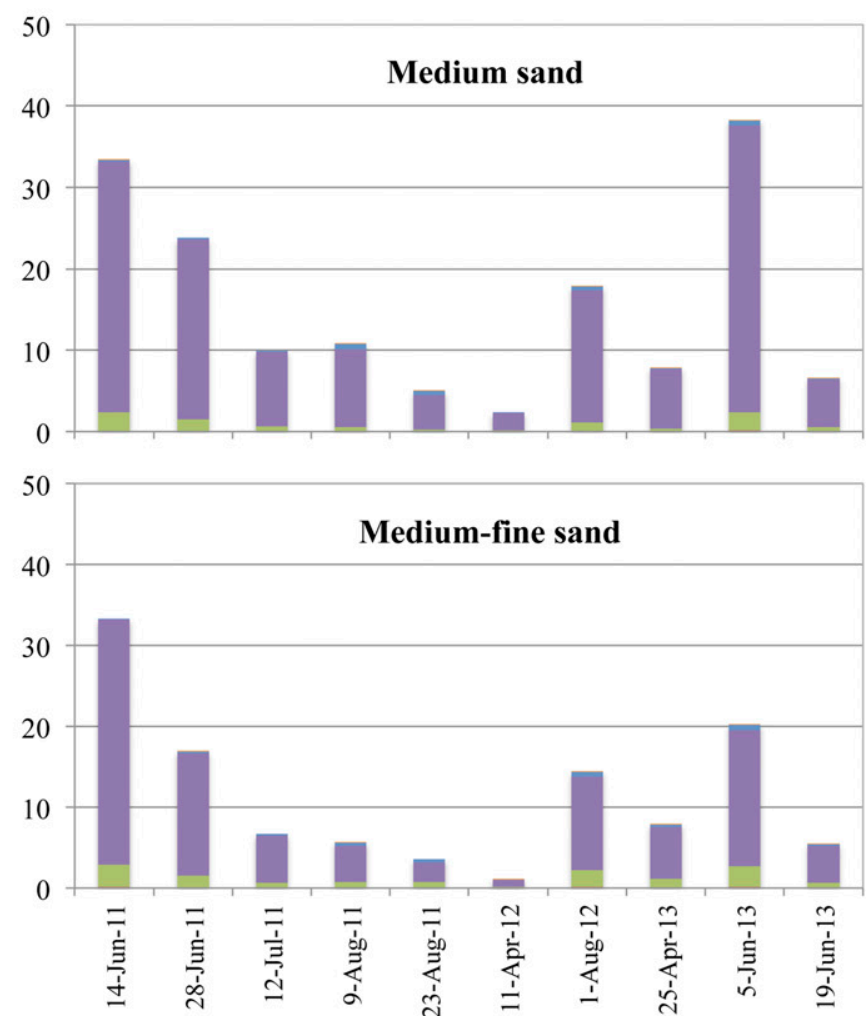

\begin{tabular}{|c|c|c|c|c|c|c|c|c|c|c|}
\hline Orthogonal contrasts & \multicolumn{10}{|c|}{ Coarse $(1-0.5 \mathrm{~mm})$} \\
\hline MC vs. M\&MF & $* * *$ & $* * *$ & $* * *$ & ** & $* * *$ & $* * *$ & $* * *$ & $* * *$ & $* * *$ & $* * *$ \\
\hline MF vs. M & NS & NS & NS & NS & NS & NS & NS & NS & NS & NS \\
\hline \multirow[t]{2}{*}{$\mathrm{CV}, \%$} & 47.4 & 58.6 & 82.5 & 71.4 & 33.3 & 58.5 & 15.4 & 69.4 & 29.7 & 52.3 \\
\hline & \multicolumn{10}{|c|}{ Medium $(0.5-0.25 \mathrm{~mm})$} \\
\hline MC vs. M\&MF & NS & NS & NS & NS & NS & $* * *$ & NS & NS & NS & NS \\
\hline MF vs. M & NS & NS & NS & $* *$ & $*$ & $* * *$ & NS & NS & $*$ & NS \\
\hline \multirow[t]{2}{*}{$\mathrm{CV}, \%$} & 29.7 & 28.2 & 36.7 & 23.1 & 26.8 & 7.7 & 22.9 & 50.7 & 37.8 & 38.6 \\
\hline & \multicolumn{10}{|c|}{ Fine $(0.25-0.15 \mathrm{~mm})$} \\
\hline MC vs. M\&MF & * & NS & NS & * & $*$ & $* * *$ & $* *$ & NS & NS & NS \\
\hline MF vs. M & NS & NS & NS & NS & $*$ & NS & $* *$ & NS & NS & NS \\
\hline $\mathrm{CV}, \%$ & 33.7 & 41.2 & 36.5 & 51.9 & 55.6 & 12.8 & 29.9 & 73.2 & 27.6 & 44.0 \\
\hline
\end{tabular}

Fig. 1. Quantity of topdressing particle sizes removed in mower clippings from annual bluegrass plots topdressed with medium-coarse (MC), medium (M), and medium-fine (MF) sands in North Brunswick, $\mathrm{NJ}$, during 2011,2012 , and 2013. ${ }^{\mathrm{Ns},}{ }^{*},{ }^{* *},{ }^{* * * *}$ Nonsignificant or significant at $P \leq 0.05,0.01$, or 0.001 , respectively.

better (on 7 Aug.) disease suppression compared with the medium-coarse sand in 2013 (Table 4). Plots topdressed with medium-fine sand had less anthracnose disease than plots topdressed with medium sand on 26 July 2013 (Table 4). coarse sand can be substantial except for two mowing events in April, when vigorous growth of $P$. annua in spring likely enables incorporation of a greater amount of topdressing. Our findings suggest that differences in the total quantity of sand removed from plots topdressed with sands of varying size were primarily due to the coarse particle contents, which are consistent with previous reports (Stier and Hollman, 2003; Taylor, 1986). The medium-coarse sand in our current study consisted of $31 \%$ of particles larger than $0.5 \mathrm{~mm}$ in diameter, whereas the medium-fine and medium sands contained less than $1 \%$ coarse-sized particles. A coarser sand, consisting of up to $61 \%$ (by weight) coarse-sized sand particles, was removed by mowing on the next day after topdressing with medium-coarse sand. The weight of fine particles removed was minimal compared with the total quantity of sand removed. Therefore, the differences between the total sand removed in mower clippings from plots topdressed with medium vs. medium-fine sand observed on 11 Apr. 2012 and 5 June 2013 were due to the quantities of mediumsized particles removed.

Similar to the lack of topdressing effect in the first year reported here, Inguagiato et al. (2012) also reported a lag in disease suppression from topdressing annual bluegrass putting green turf suggesting that sufficient sand accumulation within the turf canopy and thatch was necessary to suppress disease. Improvements in root zone properties from topdressing have not been immediately realized in other turf research studies. Topdressing creeping bentgrass putting greens reduced thatch accumulation only in the last 3 years of a 6-year study (Callahan et al., 1998), and increased water infiltration only occurred in the second year of another 2-year topdressing study (McCarty et al., 2005).

The medium-fine sand was more readily incorporated into the turf; therefore, the differences in quantities of sand removed by mowing over time could contribute to a greater quantity of sand accumulated in the plots topdressed with medium-fine sand and occasionally less disease compared with plots topdressed with medium-coarse sand. Annual bluegrass putting green turf receiving a greater annual quantity of sand topdressing was reported to have less anthracnose disease (Wang et al., 2018). Additionally, low topdressing rates during the summer were insufficient to consistently reduce the severity of anthracnose (Wang et al., 2018). However, topdressing alone is not sufficient for controlling anthracnose disease. Hempfling et al. (2017) reported topdressing in combination with other best management practices without fungicides provided acceptable disease suppression during moderate but not severe disease epidemics.

Turf with a substantial thatch layer is known to retain excessive water (Hurto et al., 1980). Topdressing sand is used to develop drier surfaces and reduce the incidence of ponding (Baker and Canaway, 1990). Conversely, turfgrass drought stress 


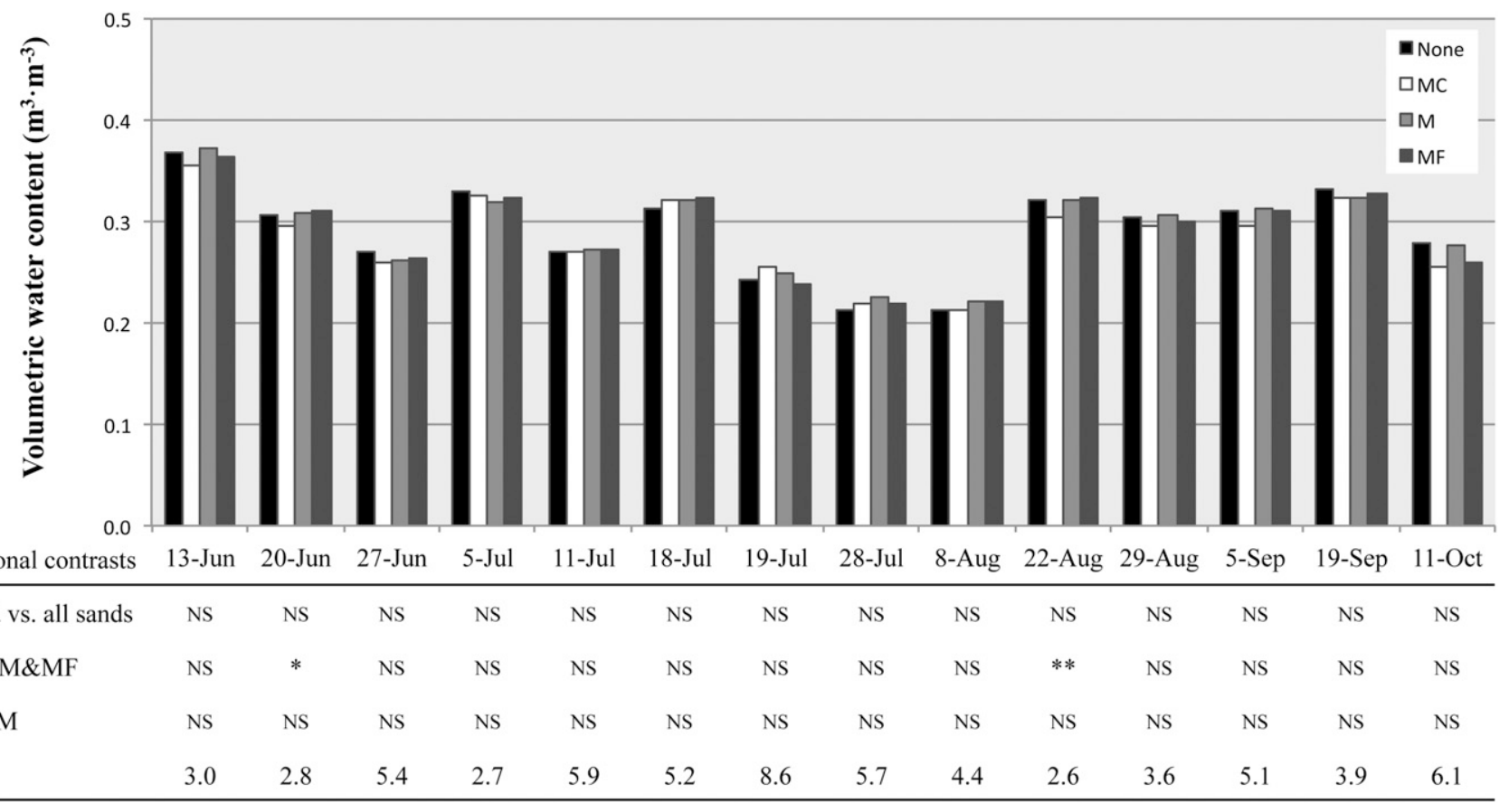

Fig. 2. Volumetric water content at the 0 - to $38-\mathrm{mm}$ depth of an annual bluegrass turf mowed at $2.8 \mathrm{~mm}$ and topdressed with medium-coarse (MC), medium (M), and medium-fine (MF) sands in North Brunswick, NJ, during 2011. ${ }^{\text {,s, }},{ }^{* * *}$ Nonsignificant or significant at $P \leq 0.05$ or 0.01 , respectively.

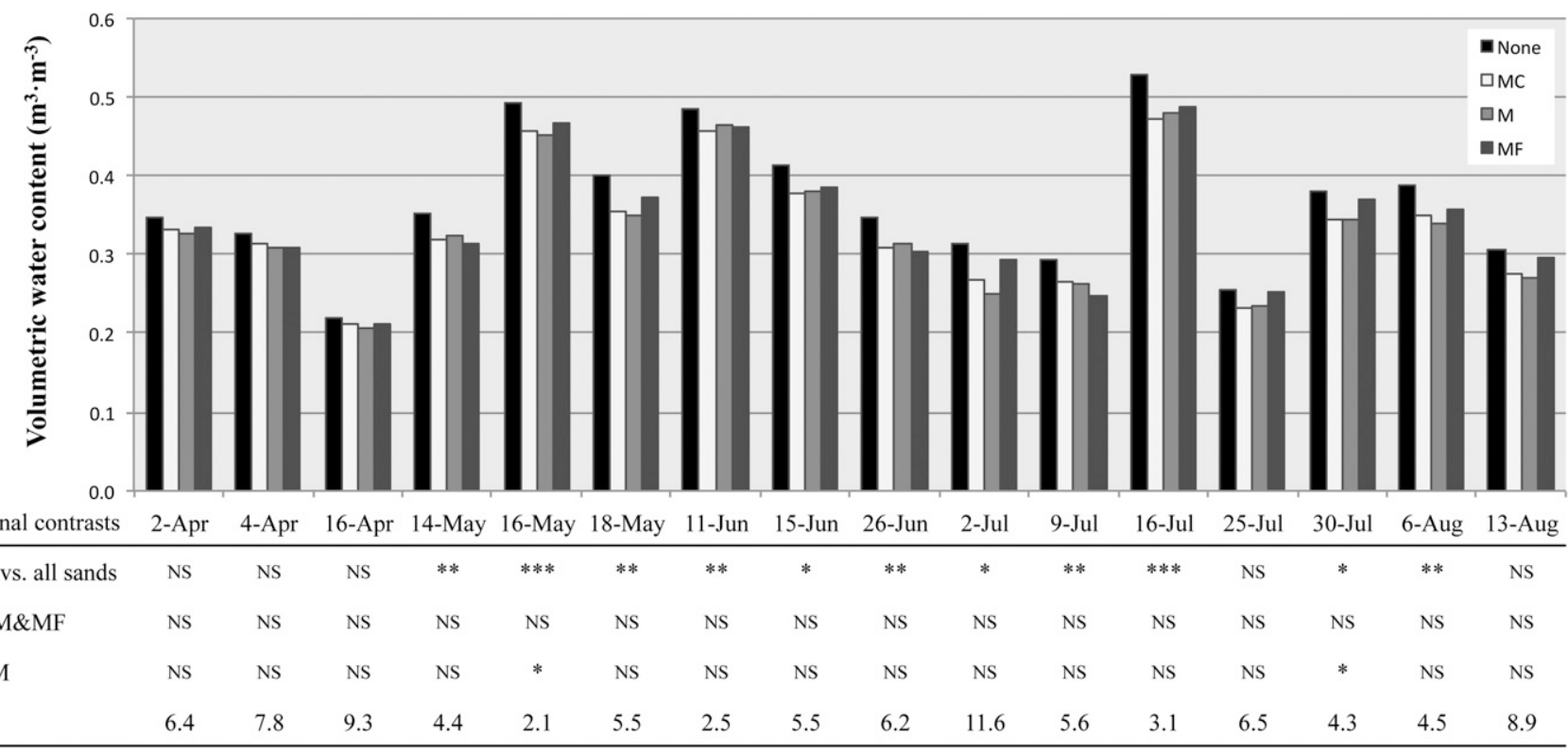

Fig. 3. Volumetric water content at the 0 - to $38-\mathrm{mm}$ depth of an annual bluegrass turf mowed at $2.8 \mathrm{~mm}$ and topdressed with medium-coarse (MC), medium (M), and medium-fine (MF) sands in North Brunswick, NJ, during 2012. ${ }^{\mathrm{Ns},}{ }^{*}, * *, * * *$ Nonsignificant or significant at $P \leq 0.05,0.01$, or 0.001 , respectively.

occurs when soil water content is too low. Roberts et al. (2011) suggested that annual bluegrass management requires avoiding either very dry or very wet soil conditions. In the current study, all topdressing sands often reduced water retention compared with the non-topdressed control; however, the VWC of plots topdressed with mediumfine sand was occasionally greater (difference $<0.03 \mathrm{~m}^{3} \cdot \mathrm{m}^{-3}$ ) than medium or medium-coarse sand plots. Additionally, anthracnose is known to intensify under insufficient irrigation (drought) of annual bluegrass turf (Roberts et al., 2011). Adequate water in the soil is essential to maintain plant health and vigor. Improved turf establishment and turf color have been attributed to greater but not excessive water retention associated with medium-fine sands compared with mediumcoarse sand (Moeller, 2008; Murphy et al., 2001; Neylan and Robinson, 1997). Therefore, less disease occasionally observed with medium-fine sand than medium or medium-coarse sand topdressed plots was likely due to higher surface water retention (less droughty).
After $\approx 3.4 \mathrm{~mm}$ of topdressing was applied in the first year, routine topdressing suppressed anthracnose of annual bluegrass turf in our study. Medium-coarse sand, which typically is recommended for topdressing, did not incorporate as well but reduced surface wetness and anthracnose; medium and medium-fine sands incorporated more readily after topdressing and also reduced surface wetness and anthracnose. Thus, negative effects of medium and medium-fine sand topdressing on VWC and anthracnose were not observed. Better incorporation and 


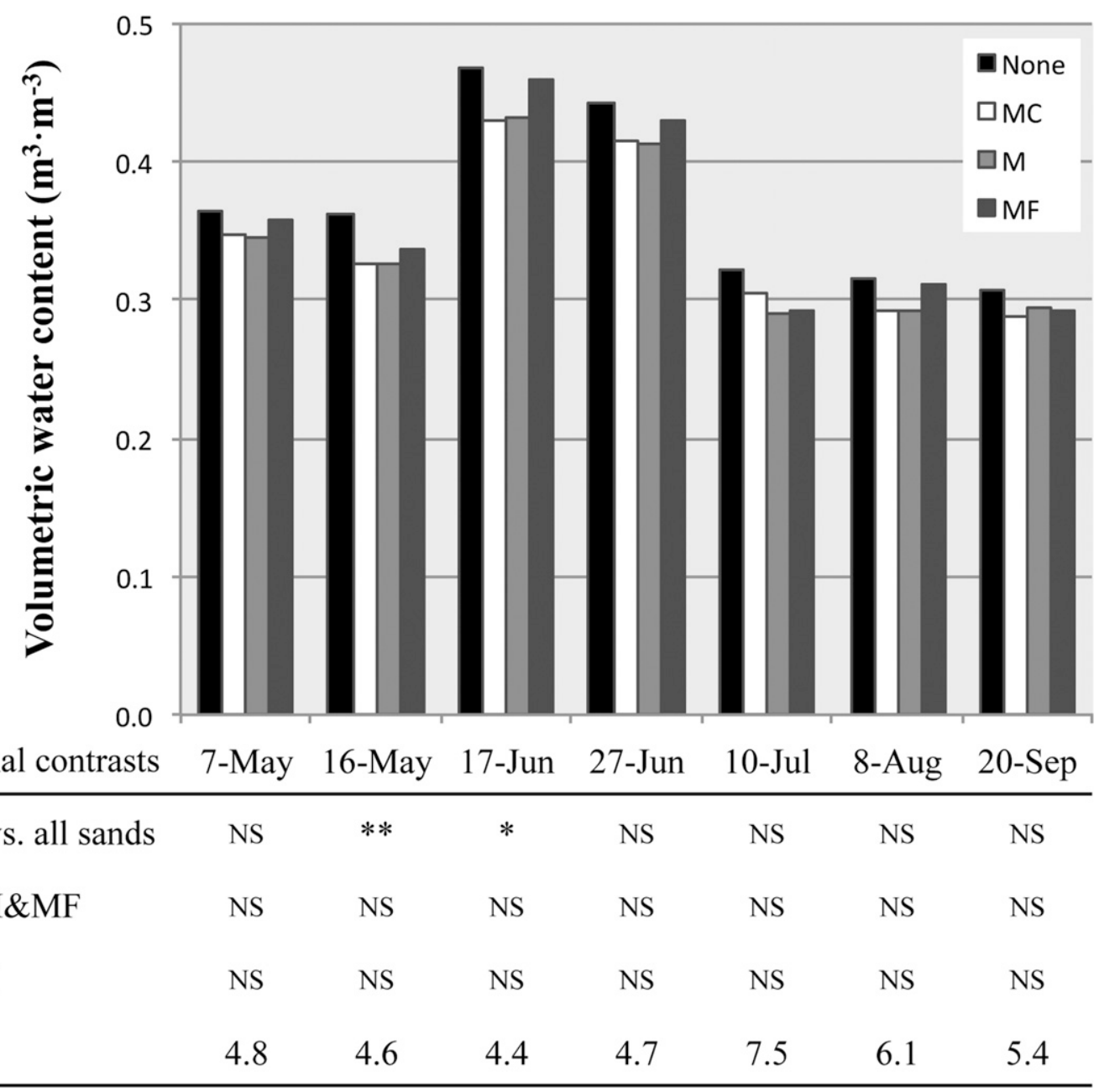

Fig. 4. Volumetric water content at the 0 - to $38-\mathrm{mm}$ depth of an annual bluegrass turf mowed at $2.8 \mathrm{~mm}$ and topdressed with medium-coarse (MC), medium (M), and medium-fine (MF) sands in North Brunswick, NJ during 2013. ${ }^{\text {Ns, }}$ *, ** Nonsignificant or significant at $P \leq 0.05$ or 0.01 , respectively.

Table 4. Anthracnose severity response on an annual bluegrass turf mowed at $2.8 \mathrm{~mm}$ and topdressed with three sand sizes in North Brunswick, NJ during 2011 , 2012 , and 2013

\begin{tabular}{|c|c|c|c|c|c|c|c|c|c|c|c|c|c|c|}
\hline \multirow[b]{2}{*}{ Sand size } & \multicolumn{5}{|c|}{2011} & \multicolumn{4}{|c|}{2012} & \multicolumn{5}{|c|}{2013} \\
\hline & 24 June & 7 July & 16 July & 5 Aug. & 16 Aug. & 27 June & 11 July & 27 July & 6 Aug. & 14 June & 8 July & 15 July & 26 July & 7 Aug. \\
\hline & \multicolumn{14}{|c|}{ Turf area infected $(\%)$} \\
\hline None & 2.2 & 4.9 & 13.3 & 74.3 & 64.7 & 4.1 & 10.3 & 33.8 & 44.0 & 11.6 & 21.6 & 36.4 & 42.6 & 71.2 \\
\hline Medium-coarse (MC) & 2.6 & 6.3 & 17.1 & 61.7 & 56.9 & 1.0 & 3.5 & 20.1 & 29.4 & 3.4 & 19.5 & 27.5 & 37.8 & 64.7 \\
\hline Medium (M) & 2.2 & 3.5 & 13.8 & 68.8 & 67.1 & 2.0 & 4.0 & 17.7 & 26.0 & 2.9 & 16.1 & 23.1 & 35.7 & 60.3 \\
\hline Medium-fine (MF) & 2.0 & 4.2 & 12.2 & 55.1 & 55.1 & 0.5 & 4.2 & 17.0 & 27.2 & 1.6 & 10.4 & 18.5 & 27.7 & 53.8 \\
\hline Orthogonal contrasts & \multicolumn{14}{|c|}{$P>F$} \\
\hline No sand vs. all sands & NS & NS & NS & NS & NS & $* *$ & $* *$ & ** & $* *$ & $* * *$ & NS & $*$ & $*$ & $* *$ \\
\hline $\mathrm{MC}$ vs. $\mathrm{M}$ and $\mathrm{MF}$ & NS & NS & NS & NS & NS & NS & NS & NS & NS & NS & NS & NS & NS & $*$ \\
\hline MF vs. M & NS & NS & NS & NS & $*$ & NS & NS & NS & NS & NS & NS & NS & * & NS \\
\hline CV $(\%)$ & 50.7 & 70.0 & 33.3 & 17.9 & 11.9 & 82.3 & 51.4 & 30.4 & 19.1 & 35.6 & 34.9 & 31.2 & 13.9 & 8.0 \\
\hline
\end{tabular}

Ns, ${ }^{*}, * *, * * *$ Nonsignificant or significant at $P \leq 0.05,0.01$, or 0.001 , respectively.

less disruption to putting surfaces with medium-fine sand topdressing would likely encourage golf course superintendents to apply topdressing more frequently or at greater quantities (or both) during summer, resulting in better turf performance and playing conditions.

\section{Literature Cited}

Baker, S.W. and P.M. Canaway. 1990. The effect of sand topdressing on the performance of winter games pitches of different construction types. I. Soil physical properties and ground cover. J. Sports Turf Res. Inst. 66:21-27.

Callahan, L.M., W.L. Sanders, J.M. Parham, C.A. Harper, L.D. Lester, and E.R. McDonald. 1998. Cultural and chemical controls of thatch and their influence on rootzone nutrients in a bentgrass green. Crop Sci. 38:181-187.

Foy, J. 1999. May the force be with you: An alternative method for incorporating topdressing sand into high-density putting green turf. U.S. Golf Assoc. USGA Green Sect. Rec. 37:27.

Hempfling, J.W., B.B. Clarke, and J.A. Murphy. 2015. Anthracnose disease on annual bluegrass as influenced by spring and summer topdressing. Crop Sci. 55:437-443.

Hempfling, J.W., C.J. Schmid, R. Wang, B.B. Clarke, and J.A. Murphy. 2017. Best management practices effects on anthracnose disease of annual bluegrass. Crop Sci. 57:602-610.

Henderson, J., N. Miller, and B. Tencza. 2010. The effect of sand type and application rate on turfgrass quality, disease severity, earthworm castings, and soil physical properties on golf course fairways. In: Annual meetings abstracts [CD]. American Society of Agronomy, Crop Science Society of America, and Soil Science Society of America, Madison, WI. 
Hurto, K.A., A.J. Turgeon, and L.A. Spomer. 1980. Physical characteristics of thatch as a turfgrass growing medium. Agron. J. 72:165-167.

Inguagiato, J.C., J.A. Murphy, and B.B. Clarke. 2008. Anthracnose severity on annual bluegrass influenced by nitrogen fertilization, growth regulators, and verticutting. Crop Sci. 48:1595-1607.

Inguagiato, J.C., J.A. Murphy, and B.B. Clarke. 2009. Anthracnose disease and annual bluegrass putting green performance affected by mowing practices and lightweight rolling. Crop Sci. 49:1454-1462.

Inguagiato, J.C., J.A. Murphy, and B.B. Clarke. 2012. Sand topdressing rate and interval effects on anthracnose severity of an annual bluegrass putting green. Crop Sci. 52:1406-1415.

Inguagiato, J.C., J.A. Murphy, and B.B. Clarke. 2013. Topdressing sand particle shape and incorporation effects on anthracnose severity of an annual bluegrass putting green. Intl. Turfgrass Soc. Res. J. 12:127-133.

Johnston, W.J., C.T. Golob, and J.P. Schnurr. 2005. Rapid, nondestructive method for separating turfgrass clippings from topdressing sand using an inclined vibrating deck. Int. Turfgrass Soc. Res. J. 10:952-955.

Landschoot, P. and B. Hoyland. 1995. Shedding some light on anthracnose basal rot. Golf Course Manage. 11:52-55.

Mann, R.L. and A.J. Newell. 2005. A survey to determine the incidence and severity of pests and diseases on golf course putting greens in England, Ireland, Scotland, and Wales. 10th International Turfgrass Research Conference, Llandudno, UK, 10-15 July 2005. Intl. Turfgrass Soc. 10:224-229.

McCarty, L.B., M.F. Gregg, J.E. Toler, J.J. Camberato, and H.S. Hill. 2005. Minimizing thatch and mat development in a newly seeded creeping bentgrass golf green. Crop Sci. 45:1529-1535.

Moeller, A.C. 2008. Evaluation of putting green surface organic matter management programs. M.S. thesis. Purdue Univ., West Lafayette, IN.

Murphy, J.A. 2012. The size of topdressing sand: Does it matter? U.S. Golf Assn. USGA Green Sect. Rec. 50:1-4.

Murphy, J.A., J.A. Honig, H. Samaranayake, T.J. Lawson, and S.L. Murphy. 2001. Creeping bentgrass establishment on root zones varying in sand sizes. Intl. Turfgrass Soc. Res. J. 9:573579.

Neylan, J. and M. Robinson. 1997. Sand amendments for turf construction. Intl. Turfgrass Soc. Res. J. 8:133-147.

Pippin, T. 2010. The five-day program: Alternative philosophy for managing your topdressing program. U.S. Golf Assn. USGA Green Sect. Rec. 48:17-19.

Roberts, J.A., J.C. Inguagiato, B.B. Clarke, and J.A. Murphy. 2011. Irrigation quantity effects on anthracnose disease of annual bluegrass. Crop Sci. 51:1244-1252.
Roberts, J.A. and J.A. Murphy. 2014. Anthracnose disease on annual bluegrass as affected by foot traffic and sand topdressing. Plant Dis. 98:13211325 .

Samaranayake, H., T.J. Lawson, and J.A. Murphy. 2008. Traffic stress effects on bentgrass putting green and fairway turf. Crop Sci. 48:11931202.

Smiley, R.W., P.H. Dernoeden, and B.B. Clarke. 2005. Compendium of turfgrass diseases. APS Press, St. Paul, MN.

Stahl, J. 2013. Does size matter? Golf Course Industry. 25(1):58, 60, 61, 64.

Stier, J.C. and A.B. Hollman. 2003. Cultivation and topdressing requirements for thatch management in $A$ and $G$ bentgrasses and creeping bluegrass. HortScience 38:1227-1231.

Taylor, D.H. 1986. Points of caution: Sand size for topdressing golf greens. Golf Course Manage. $54: 50,52,54,58,60,62$.

United States Golf Association Green Section Staff. 2004. USGA recommendations for a method of putting green construction. U.S. Golf Assn., Far Hills, NJ.

Vavrek, R.C. 1995. A successful topdressing program requires consistency, commitment, and communication. U.S. Golf Assoc. USGA Green Sect. Rec. 33:8-10.

Wang, R., J.W. Hempfling, B.B. Clarke, and J.A. Murphy. 2018. Seasonal and annual topdressing effects on anthracnose of annual bluegrass. Agron. J. 110:2130-2135. 